\title{
名古屋大学 下木戸隆司
}

The effect of target degradation on detection of semantic satiation in a lexical decision task

Takashi Shimokido (Department of Psychology and Human Developmental Sciences, Graduate School of Education and Human Development, Nagoya University, Furo-cho, Chikusa-ku, Nagoya 464-8601)

In this study, it was examined whether or not visual quality of letter strings influenced the detection of semantic satiation in a lexical decision task. Previous studies concluded that lexical decision tasks cannot detect semantic satiation, because semantic information was not fully utilized in this task. Recently, however, it has been shown that semantic satiation is detected in this task as long as semantic information of the target was fully utilized. This study examined whether or not semantic satiation in the lexical decision task is found when a visually degraded target was presented. Forty-eight college students participated in the experiment. Semantic satiation was found in the degraded target condition, but not found in the intact target condition, which was consistent with the previous studies. These results suggest that this effect in the lexical decision task is found only if the target is degraded, and semantic information of the target is available for the decision.

Key words: semantic satiation, visual degradation, lexical decision.

“くも, くも, くも, くも, ….”.などという具合 に，同じことばを何度も繰り返していると次第にその 意味が消えていき，奇妙なものに感じられることがあ る.同様のことは長時間同じことばを凝視し続けるこ とでも生じる，意識的に経験されるこのような一時的 な意味の消失は意味飽和 (semantic satiation) と呼ば れ, 古くから研究者の関心を集めてきた (Severance \& Washburn, 1907). 長年の間, 意味飽和の研究者は この現象を捉える方法を模索してきたといえる. 当初 は，主観的に感取される意味の質感が長時間同じこと ばにふれていることでどのように変容されるのかが， 内観法を用いて研究された. 後になると, 提示された 語から連想される語の想起頻度 (Smith \& Raygor, 1955）や，SD 法での評定值（Lambert \& Jakobovits, 1960）が飽和の前後でどのように変化するのかが着目 されるようになった。しかしながらこれらの測度を用 いた研究は, 方法論や結果の再現性に問題点を有して おり, 現象の存在自体が疑問視されたため（Esposito \& Pelton, 1971), 今日ではほぼ完全に下火となってい る.

一方 Neely (1977）は, 意味飽和の測度として意味

\footnotetext{
本論文は, 名古屋大学大学院教育学研究科に提出された修 士論文の一部に加筆・修正したものである.

2 論文の作成にあたりご指導頂いた名古屋大学岡田猛先生に 深く感謝いたします。
}

的プライミング効果に着目し, 飽和の影響は効果の減 少分として捉えられるのではないかと考えた。意味的 プライミング効果は, 最初に提示された語（プライ ム, 例：医師）と意味的に関連する語（ターゲット， 例：看護師）が提示されると, 関連しない語（例：パ ン）が提示されたときよりも反応が早く，正確になる 現象として知られている (Neely, 1991). 具体的には, プライムを長時間提示することで慣れや疲労による抑 制が意味ネットワーク内で生じるため，プライミング 効果が減じられると予想できる。つまり疲労や順応に よって意味ネットワークに扔ける各ノードの活性が低 下するため，ノードが予め活性化しているアドバンテ ージが削がれ，意味的プライミング効果が減じられる と考えられる。この予想は Neely 自身の実験では支持 されなかったが，その後 Smith（1984）によって確認 され, 最近では意味飽和の測度として広く採用されて いる.

近年の研究を概観すると，実験でどのような課題を 用いるかで異なった結果が認められるようである，具 体的には，カテゴリー判断課題が用いられた場合と語 彙判断課題が用いられた場合とでは, 実際に得られる 結果が違ってくる. カテゴリー判断課題は，プライム (例：スポーツ）とターゲット（例：テニス）が同じ カテゴリーに属するかを判断させたり (Smith, 1984), 対提示されるターグット（例：マグロ・イワ 
シ）がともに同じカテゴリーに属するかを判断させた

り（Smith \& Klein, 1990）する課題のことを指す。こ れらの課題は内容に若干のバリエーションがあるもの の，長時間のプライム反復によるプライミング効果の 減衰が安定的に認められている (Balota \& Black, 1997; Pilotti, Antrobus, \& Duff, 1997; Smith, 1984; Smith \& Klein, 1990). その反面, 単一提示された文 字列が単語であるか非単語であるかを判定しなければ ならない語彙判断課題が採用された場合には，一貫し て確認されていない (Cohene, Smith, \& Klein, 1978; Neely, 1977; Smith, 1984).

こうした結果の不一致がなぜ生じるのか，とくにな ぜ語彙判断課題でプライミング効果の減衰が認められ ないのかに関しては，いくつかの解釈が提案されてい る。一つには，非意味的な要因による影響の受けやす さがある.語彙判断課題では文字列の単語らしさや親 近性に基づいて判断できるので，ターゲットの意味情 報があまり利用されていない可能性が考元られる (Smith，1984)。またプライムとターゲットの意味的 な整合性に基づいて語彙判断を行う傾向が，ターゲッ トへの十分な意味アクセスを妨げている可能性も考え られる (Balota \& Black, 1997; Black, 2001). 被験者 はターゲットがぞういったものであるかを詳しく分析 する以前に，プライムと関連していそうなら単語と判 断し，そうでないなら非単語と判断する方略をとる傾 向があることが知られているためである（Neely, Keefe, \& Ross, 1989). どちらの解釈でも, 語氣判断課 題では夕ーゲットの意味情報が十分に利用されていな いために，長時間のプライム反復によって生じる意味 レベルでの抑制の影響を適切に検出できていないと捉 える点では共通している。

それに対して，カテゴリー判断を行う課題ではター ゲットの意味情報が否応なしに利用されるため, 意味 ネットワーク内で生じた抑制の影響をプライミング効 果の減衰として捉えることができると解釉される (Smith, 1984; Smith \& Klein, 1990).もしこれが正し いのだとすれば，ターゲットの意味情報が十分に引き 出され，アクセスされるような状況を設けてやりさえ すれば，語彙判断課題であってもプライミング効果の 減衰を検出できるはずである.

しかし一方で, 語彙判断課題でプライミング効果の 減衰が認められない理由として, 語彙判断課題の負荷 量が飽和を検出できる水準に達していなかったためと いう考え方も可能である (下木戸，2003）．カテゴリ 一判断課題はターゲットがあるカテゴリーに属するか 否かを判定するため, ターゲットとカテゴリー語を比 較し, 判断を下さなければならない。 それに対し, 語 彙判断課題はターグットが単語であるかを判定するだ けですむ. 複数の語を比較し, 判断を下さなければな
処理負荷を要するといえる，つまり，比較や決定とい った，いわゆる語彙アクセス後（post-lexical）の処理 過程での違いが結果の差を生みだしたと解釈できる. この考え方を敷衍するなら，判断の際に複数の語を比 較させる状況を設定すれば, 語彙判断課題であっても プライミング効果の減衰を検出できることになる. 実 際に下木戸 (2003) は, 対提示されるターゲットの語 彙性（単語か否か）が同じであるかを判定させる二重 語彙判断課題を用いたとき, プライミング効果が減じ られることを見出している。

意味情報の利用が促されれば語彙判断課題であって も意味飽和を検出できるのか, それとも比較や決定と いった語彙アクセス後の処理がある程度行われれば検 出できるのかに関しては, 現段階では十分な証拠が蓄 積されておらず，はっきりしていない。この問題を検 討する一つの手段としては，ターゲットを視覚的に劣 化させるというものが考えられる。

視覚的な劣化（visual degradation）は文字列の質を 意図的に落として，見づらくさせる操作として知られ ている。この効果は, 意味的関連性の効果と交互作用 を有することが報じられている（Becker \& Killion, 1977; Besner \& Smith, 1992; Meyer, Schvaneveldt, \& Ruddy, 1975). 例えば Meyer et al. (1975) は，プライ ムとターゲットが意味的に関連するときには劣化の影 響はそれほどでもないが，プライムとターゲットが関 連しないときは劣化による影響が大きくなることを見 出した。こうした交互作用がなぜ見られるのかに関し ては，以下のように説明できる。つまりプライムと夕 ーゲットとが意味的に関連する場合には，ターゲット の劣化によって生じた知覚情報の不足分を意味情報に よって埋め合わせることができるため，視覚的な文字 列の質の影響をそれほど受けなくてすむ。しかしプラ イムとターゲットが関連しない場合には，意味情報に よる埋め合わせができないので，文字列の質の影響を 大きく受けてしまうというわけである (Becker \& Killion, 1977; Stanovich \& West, 1979).

ところで，なぜターゲットが劣化されることで夕ー ゲットの意味情報の利用が促されるのであろうか。こ の点に関しては, Balota \& Chumbley（1984）の二段 階モデルを用いて以下のように説明することが可能で ある、まずターゲットが視覚的に劣化されることで夕 ーゲットの視認性が悪化し，単語と非単語の弁別可能 性が低下する。これは単語らしさや親近性といった点 で単語が非単語に対して有していたアドバンテージが 削がれることを意味する。これらの間の弁別可能性が 低下寸ることで，文字列の親近性や有意味性に基づい た判断（第一段階）が困難になり，そのため，より精 緻で分析的な処理（第二段階）が優勢となる. 語彙ア クセスはこの第二段階で行われると考えられる。語彙 アクセスに基づく処理が優勢になることで, 意味情報 
の関与も高められることになるわけである。それに対 して, ターダットが劣化されていない場合は，第一段 階の処理も行われやすいために意味情報の関与も低く なると考えることができる。

またそれに加えて, 視覚的な文字列の質の低下は間 接的にも意味情報の関与を高めることが期待される. 意味アクセスは時間の経過とともに進行すると想定さ れるので, 文字列が劣化され，処理時間が増えること に伴って意味情報の影響力が増すことになると考えら れるためである. 反応時間が長くなるほどプライミン グ効果も大きくなる傾向が報じられているが（Neely et al., 1989; Stanovich \& West, 1979)，これも処理時間 が増えることで意味情報の影響力が増すためと解釈で きる.

そこで本研究では, 長時間プライムを提示すること で生起する飽和の影響が, 語の認知過程のどの段階に 現れるのかを検討する。具体的には，ターゲットを視 覚的に劣化させて提示した場合に, 長時間プライムを 反復させることでプライミング効果が減じられるかに 関して検討を行う。ターゲットを劣化させることで語 彙判断時における意味情報の利用が促されるので, 反 復によって生じた意味アクセスの抑制の影響を適切に 捉えることができると想定される。もし意味飽和の検 出にとってターゲットの意味情報の利用が重要である ならば, 語彙判断課題であってもそれがプライミング 効果の減衰となって現れると予想される。一方で, も し語彙アクセス後の処理過程の違いが重要であるなら ば，ターゲットを劣化させて提示したとしてもターゲ ットを単一提示している点は変わらないから, 多数回 プライムを反復させてもプライミング効果は隇じられ ないだろう。

加えて本研究ではターゲットを劣化させない原形状 態で提示した場合に，プライムの反復によってプライ ミング効果が減じられるかに関しても検討を試みる。 下木戸（2003）が用いた刺激セットには普段見慣れて いない表記のものが含まれていたため, それが夕ーゲ ットの意味情報の利用を促し (Balota \& Chumbley, 1984), 意味飽和を検出させた可能性が考えられる. もし見慣れない表記のものが混じることで通常以上に 意味情報の利用が促されるのであれば，ターゲットが 原形状態で提示される語彙判断課題であってもプライ ミング効果が減じられるのかもしれない.つまり文字 列が劣化されていようがいまいが，この刺激セットが 用いられる限り意味飽和が検出されるのかもしれな い. 本研究ではこの可能性についても検討する.

\section{方法}

被験者 成人男女 48 名が実験に参加した。

実験計画 以下の三つの要因が設定された。第一の 要因は意味的関連性に関する要因であり,プライムと
ターゲットが意味的に関連する条件と関連しない条件 の 2 種類であった. 第二の要因は刺激の提示回数に関 する要因であり,プライムを 3 回提示する条件と 30 回提示する条件の 2 種類であった. 第三の要因は文字 列の視覚的な質に関する要因であり, 劣化された状態 で提示される条件と劣化されていない原形状態で提示 される条件の 2 種類であった。これらのうち意味的関 連性と反復の要因は被験者内要因として, 文字列の質 は被験者間要因として設定された。

装置 刺激の提示, 反応の測定を含めた実験制御に はパーソナル・コンピュータ（NEC PC-9821Xs）お よび 15 インチ・ディスプレイ（Mitsubishi RD15DII） を使用した。一文字当たりの大きさは視覚で水平方向 に約 0.7 度 $\times$ 垂直方向に約 0.9 度であった（観察距離 約 $50 \mathrm{~cm})$.

刺激材料 刺激となるカテゴリー語 32 語, カテゴ リ一事例語 128 語は，下木戸 (2003) と同様に，秋田 （1980）や小川（1972）のカテゴリー出現頻度表をも とに構成され, 出現頻度が中程度（35-40）以上にな るものが選出された。その際にできるだけ文字数を均 等にするために，ターゲットに関してのみ，漢字で表 記される語は平仮名で表記した。 その後, カテゴリー 語と事例語はそれぞれプライムとターゲットとして対 にされ，32対からなる四つのリストに分割された。 それぞれのリストの半数はターゲットが単語となる Yes 反応対であり, 残りの半数がターゲットが非単語 となるNo 反応対であった。非単語は語の字を並べ替 えることによって作成された (例：ブコン). Yes 反 応対のうちの半数はプライムとターゲットとが意味的 に関連する組み合わせであり（例：昆虫・バッ夕）, 残り半数の Yes 反応対が意味的に関連しない組み合 わせであった（例：昆虫・ルビー)。実験ではこれら のリストの中から二つを使用した。その際に, 一方で Yes 反応対であったものは他方で No 反応対に，また 一方でNo 反応対であったものは他方で Yes 反応対に なるように配置された。セッション間の刺激リストの 提示順序や反復提示回数への割り当て, 使用リストの 種類は被験者間でカウンターバランスされた。被験者 の半数にはターゲットが視覚的に劣化された状態で提 示され, 残りの半数には劣化されていない状態で提示 された。

手続き 実験は各被験者に対して個別に行われた。 各試行では, 最初に注視点列が 1 秒間画面中央に提示 された後， $200 \mathrm{~ms}$ のブランクを挟んで，プライムが 反復提示条件が定める回数だけ画面中央に反復提示さ れた。 それぞれのプライムは $500 \mathrm{~ms}$ 提示された後, 画面上から消去され, $200 \mathrm{~ms}$ のブランクを挟んでか ら再提示された。また最後の刺激提示の際には, 夕一 ゲットの提示を予告するシグナルとしてビープ音が $60 \mathrm{~ms}$ 鳴らされた。被験者は，(a)反復提示されるプ 
ライムを画面上に現れる都度声に出して音読するよう に，(b)途中でビープ音が聞こえたら，その1秒後に 提示されるターゲットに備えるようにと予め教示され ていた。続いてターゲットが画面中央に提示された。 劣化条件では, ターゲットは 122 個のランダム・ドッ トで覆われた後, 刺激として提示された（Figure 1).被験者は，そこで夕ーゲットが単語であるのか, それとも単語ではないのかの判断をマウスのボタンを 押すことによって行った。具体的には，ターグットが 単語であればマウスの左のボタンを，そうでなければ 右のボタンを，できるだけ早く，かつ正確に押すよう に求められた。な打判断の際には，文字列の濁点や半 濁点の有無に気を取られすぎないようにも予教示さ れていた。被験者がいずれかのボタンを押し，反応時 間および反応ボタンが取得されるとともにターゲット は消え，2秒のインターバルをおいて次の試行に移つ た。

練習を行った後, 被験者は 64 試行からなる本試行 に入った。本試行で与えられる刺激の順序は同一の反 復刺激提示条件下のものが 3 回以上連続して出現しな いように，被験者ごとにランダムに並べ替えられた。 また本試行は 32 試行ずつ二つのセッションに分割さ れ，セッションの間には 2 分間の休㖃が挟まれた。

\section{結果}

誤反応が得られた試行を除いて，反応時間はすべて 対数変換が施されてから統計処理が行われた. Table 1 亿各条件における平均反応時間および詰反応率を示 す3. 反応時間に関して分散分析を試みたところ，プ ライムとターゲットが意味的に関連している条件の方 が関連していない条件よりも反応が早く $(F(1,46)=$ $92.12, p<.001)$, 意味的プライミング効果が認められ た。また反復の主効果も確認され，プライムを 30 回 反復した条件の方が 3 回反復した条件よりも反応が遅 くなっていた $(F(1,46)=5.11, p<.05)$. 文字列の質 の主効果も有意であり, 劣化された文字列が提示され た条件の方が原形状態の文字列が提示された条件より も反応が遅くなっていた $(F(1,46)=39.30, p<$ .001). 同様に意味的関連性 $\times$ 文字列の質 $(F(1$, 46) $=7.10, p<.05)$, 反復 $\times$ 文字列の質 $(F(1,46)=$ $4.22, p<.05)$ の交互作用も有意であり, 意味的関連 性や反復の効果はどちらも劣化された文字列が提示さ

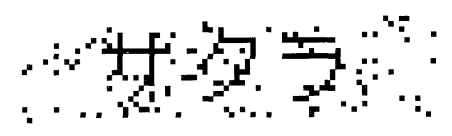

Figure 1. Example of the target stimulus used in the experiment.

反応時間の平均值には幾何平均を用いた。
Table 1

Geometric mean reaction times (ms) and percent errors as a function of visual target quality

\begin{tabular}{lrrrr}
\hline \multirow{2}{*}{ Condition } & \multicolumn{2}{c}{3 repetitions } & \multicolumn{2}{c}{30 repetitions } \\
\cline { 2 - 5 } & RT & \% errors & RT & \% errors \\
\hline Degraded & & & & \\
Related & 674 & 3.1 & 733 & 5.2 \\
Unrelated & 794 & 17.2 & 808 & 15.6 \\
difference & 120 & 14.1 & 75 & 10.4 \\
Intact & & & & \\
Related & 560 & 2.6 & 548 & 2.6 \\
Unrelated & 588 & 8.3 & 604 & 7.3 \\
difference & 28 & 5.7 & 56 & 4.7
\end{tabular}

れた条件の方が，原形状態の文字列が提示された条件 よりも大きくなっていた。意味的関連性 $\times$ 反復 $\times$ 文字 列の質の交互作用も有意であったものの $(F(1,46)=$ $7.74, p<.01)$, 意味的関連性と反復の交互作用は有意 ではなかった $(F(1,46)<1, n s)$.

分散分析の結果，意味的関連性 $\times$ 反復 $\times$ 文字列の質 の交互作用が認められたので，文字列の質条件のもと で単純交互作用の分析を行った。その結果，劣化され た文字列が提示された場合に意味的関連性 $\times$ 反復の交 互作用が確認されたものの $(F(1,46)=5.13, p<$ .05)，原形の文字列が提示された場合には認められな かった $(F(1,46)=2.79, n s)$.さらに分析を進めたと ころ，劣化された文字列が提示され，なおかつプライ ムとターグットが意味的に関連している場合に，プラ イムが 30 回提示された条件の方が 3 回提示された条 件よりも遅くなっていた $(F(1,92)=14.34, p<$ .001).プライムとターゲットが関連しない場合や $(F(1,92)<1, n s)$, 原形の文字列が提示された場合 には両者の間に差は認められなかった $(F(1,92)<1$, $n s ; F(1,92)=1.47, n s)$. プライムとターゲットが意 味的に関連する場合には反復条件間に差が見られ，関 連しない場合には見られないことから，プライムを長 時間反復させることで生じる反応の遅延は，プライム とターダットが意味的に関連することで生じる反応の 促進を弱める形で認められた。つまり反復の影響は意 味的プライミング効果を減じる方向で現れていた。こ うした傾向は視覚的に劣化された文字列が提示された 場合にのみ確認された。

次に, プラ゙イム反復回数の違いによって意味的関連 性 $\times$ 文字列の質の効果がどの程度異なってくるのかを 見るため, 反復条件のもとで単純交互作用の分析を試 みた。その結果, プライムを 3 回提示した場合には意 味的関連性 $\times$ 文字列の質の交互作用が認められたもの の $(F(1,92)=14.81, p<.001), 30$ 回提示した場合に は認められなかった $(F(1,92)<1, n s)$.つまりプラ 
イムを 3 回提示した場合には，劣化された文字列が提 示された条件の方が, 原形状態の文字列が提示された 条件よりも意味的関連性の効果は大きくなっていた。

誤反応率に関しては逆正弦变換が行われた。分散分 析を試みたところ, 意味的関連性 $(F(1,46)=24.30$, $p<.001)$, 文字列の質 $(F(1,46)=4.70, p<.05)$ の 主効果が有意であり, プライムとターゲットが意味的 に関連している条件の方が関連していない条件よりも 誤反応が少なく, また劣化された文字列が提示された 条件の方が原形の文字列が提示された条件よりも誤反 応が多くなっていた。しかし残りの効果に関してはす べて有意ではなかった（反復 $\times$ 文字列の質 $(F(1$, 46) $=1.55, n s)$ を除きすべて $F(1,46)<1, n s)$.

\section{考察}

単一の文字列に対する語彙判断課題ではこれまで一 貫して意味飽和は検出されてこなかった (Cohene et al., 1978; Neely, 1977; Smith, 1984). 本研究では夕ー ゲットを視覚的に劣化させて提示すれば，意味飽和を 検出することができるのではないかという予測を立 て, 実験を行った。以下の考察では，(a)劣化操作は 意味飽和の検出にどれだけの影響を及ぼしたのか, (b) 従来の語彙判断課題ではなぜ意味飽和が検出され なかったのか, (c) 意味飽和はどの処理段階で生じて いると考えられるか, (d) 本研究で語彙判断課題を用 いたことの意義はどこにあるのか，といった観点から 議論を行う。

\section{視覚的な文字列の質による影響}

ターゲットを視覚的に劣化させることは，意味飽和 の検出に実際にどのような影響を及涩したのであろう か. 検討すべき点は，意味的関連性 $\times$ 反復 $\times$ 文字列の 質の交互作用と意味的関連性 $\times$ 文字列の質の交互作用 についてである，前者は意味飽和の点から，後者は文 字列が視覚的に劣化されることで, 語彙判断時に意味 情報の利用が実際に促されていたのかに関する指標を 提起する点で重要と考えられる。

意味的関連性 $\times$ 反復 $\times$ 文字列の質 この効果は意味 飽和の指標となるため, 最も重要なものである.夕ー ゲットが視覚的に劣化された条件では, 長時間プライ ムを反復することで意味的プライミング効果が減じら れていた。この結果は, 単一文字列に対する語彙判断 課題であっても, ターゲットを劣化させて提示すれば 効果の減衰を検出できることを示すものである. ター ゲットが視覚的に劣化されることで, 単語と非単語の 弁別可能性が低下する。そのことが結果的に, 語彙判 断時における意味情報の関与を高め, 意味飽和の検出 をもたらしたと考えられる。つまりこの結果は, ター ゲットの意味情報が十分に利用されることが意味飽和 の検出にとって重要とした当初の予測を支持するもの
といえる。

それに対して語彙アクセス後の処理負荷が効果の減 衰の検出にとって重要であるとする予測は, この結果 を見る限り，支持されなかったといえる．また一方 で, ターゲットが劣化されていない原形状態で提示さ れた条件ではプライミング効果の減衰は認められなか った.このことから，劣化条件において見られたプラ イミング効果の減衰は見慣れない表記を用いたことに よるアーティファクトではなく, 文字列を劣化させた ことによる効果を反映していたと考えられる.

意味的関連性 $\times$ 文字列の質 劣化条件での意味的関 連性の効果が原形条件のものよりも大きくなるという 結果は, 語彙判断時における意味的要因の関与が劣化 条件で大きくなっていたことを示すものとして捉える ことができる (Besner \& Smith, 1992; Lukatela \& Turvey, 1987; Stanovich \& West, 1979).この効果が本 研究で認められた点は注目に值する。というのは, 本 研究で用いられたターグットはすべて平仮名か片仮名 で表記されていたが，仮名表記は言語学でいうところ の規則的な正書法 (shallow orthography) 該当する と考えられるためである。規則的な正書法を有する言 語では表記と発音が 1 対 1 に対応しているため, その 対応規則さえ習得していれば文字列を音読できるとい う性質がある.こうした言語では語彙判断を行う際に 意味的な要因の関与をとくに必要としないため, 意味 的関連性 $\times$ 文字列の質の交互作用は認められないと予 想される (Lukatela \& Turvey, 1987).しかしながら 本研究では，仮名表記刺激を用いたにもかかわらず， 予想に反してこの交互作用が認められた。ただ近年で は，規則的な正書法を有する言語であっても意味的関 連性×文字列の質の交互作用が認められる場合がある ことが報じられており（Bajo，Burton，Burton，\& Canas, 1994; Lukatela, Carello, Peter, Lukatela, \& Turvey, 1996), これらの言語に扔ける意味的要因の 影響が当初考えられていた以上に複雑であることが示 されてきている，本研究の結果はこうした傾向に整合 するものといえる.

ところで本研究では, 意味的関連性 $\times$ 反復 $\times$ 文字列 の質の交互作用が有意であり, プライムを 3 回提示し た場合には意味的関連性 $\times$ 文字列の質の交互作用が確 認されたものの, 30 回提示した条件で意味的関連 性 $\times$ 文字列の質の交互作用は認められなかった。この 結果は, プライムを 30 回提示した条件でプライミン グ効果が減じられたことを反映したものと考えられ る. 意味的要因の関与が弱まったことを示唆する点 で, これは意味飽和を別の側面から捉えたものと解釈 されよう。

\section{語彙判断課題と意味飽和}

なぜ単一文字列に対する語彙判断課題では，これま 
で意味飽和を検出できなかったのだろうか（Cohene et al., 1978; Neely, 1977; Smith, 1984). 先に単語らし さ，親近性といった非意味的要因やプライムとターゲ ットの意味的整合性に基づく反応のバイアス等をその 理由として挙げた。本研究における劣化条件では，夕 ーゲットは劣化された見づらい状態で提示されたこと で単語と非単語が弁別しづらくなっていた。これによ り，単語らしさや親近性といった要因による影響は小 さくなっていたと推測される。つまり，その分ターゲ ットの意味情報が利用されたと考えられる。その反 面，ターゲットが劣化されなかった原形条件では，単 語らしさや親近性による影響が比較的大きく，ターゲ ットの意味情報はあまり利用されなかったと推測され る. 下位検定の結果，劣化条件でプライミング効果の 減衰が認められ，逆に原形条件で認められなかったの は，この可能性を支持するものと解釈できる.

一方で，プライムとターゲットの意味的整合性に基 づくバイアスが意味飽和の検出を阻んできた可能性に 対しては，本研究からはそれを積極的に支持する証拠 は得られていない.関連比率 (relatedness proportion）や非単語率（nonword ratio）などといった要因 は意味的整合性に基づく反応バイアスの形成に影響を 及ぼすことが知られているが (Neely et al., 1989)，視 覚的な文字列の質の条件間でこれらの值が一定であっ たにも関わらず，劣化条件ではプライミング効果の減 衰が確認され，原形条件では確認されないという具合 に結果が分かれているからである。関連比率愔単語の 総数に対して，プライムとターゲットが意味的に関連 する試行が占める割合として定義される。一方，非単 語率はプライムとターダットが関連しない試行の総数 に対して，非単語が占める割合として定義される。こ れらの值が高い状況ではプライムとターゲットの意味 的整合性に基づく反応バイアスが生起しやすくなり， 逆にこれらの值が低い状況では生起しにくくなること が知られている。本研究における関連比率は特筆すべ き值でないが $(.50)$, 非単語率は比較的高い值を保っ ており (.67)，この反応バイアスが生じやすい状況に なっていた，それにもかかわらず，劣化条件ではプラ イミング効果の隇衰が確認された点は注目すべきであ ろう.

本研究では劣化条件，原形条件ともに非単語率は一 定であったそそのため，劣化条件に関してのみプライ ムとターゲットの意味的整合性に基づく反応バイアス が起こりにくくなっていたとは考えにくい（Neely， 1991).ターゲットが見やすかろうと，見にくかろう と，それが単語，あるいは非単語である確率は変わら ないからである、結局のところ本研究の結果から判断 する限り，意味的整合性に基づく反応バイアスによっ て意味飽和の検出が妨げられてきた可能性は低いとい

\section{抑制の位置}

長時間のプライム反復によって抑制が生じているな らば，それはいったいどこで生じていると考えられる だろうか. カテゴリー判断課題 (Smith， 1984; Smith \& Klein, 1990) や二重語彙判断課題（下木戸，2003） でプライミング効果の減衰が認められたことにより, この抑制は比較や決定等の語彙アクセス後の処理過程 で生じている可能性が疑われた。しかし本研究で，劣 化された文字列に対する語彙判断課題でも効果の減衰 が認められたことにより，その可能性は幾分か弱めら れたといえる。というのは, 文字列の質の要因は語の 認知過程の比較的初期の段階で影響すると仮定される ことが多いため (Besner \& Smith, 1992; Meyer et al., 1975)，抑制も語彙アクセスが行われる以前（prelexical）の段階で生じている可能性が示唆されたため である，そこで考えられるのが，抑制は知覚処理のご く初期の段階で作用しており，それが後の意味処理に 影響を及ぼすのではないかという可能性である。実際 に Esposito \& Pelton (1971) や Pilotti et al. (1997) は，長時間同じ刺激に接触していることで疲労や順応 が生じ，知覚対象が別の新たなものへと転化させられ るため, 元の知覚対象に対応した意味が減衰し, 消失 するのではないかと主張している。この見解は， Kounios, Kotz, \& Holcomb（2000）によって，声のピ ッチなどの超特異的（hyperspecific）な情報に鋭敏な 段階で生じている可能性は弱められたものの, それよ り後のより高次の知覚処理段階で生じている可能性は 依然として残されている。 また Pilotti et al. (1997) のように意味処理との相互作用が推察される結果も報 告されていることから，知覚処理における抑制の位置 に関しては今後も慎重に検討していく必要がある。

もし飽和の影響が語彙アクセス前の処理過程で現れ るのであれば，下木戸（2003）が行った二重語彙判断 課題やカテゴリー・マッチング課題で意味飽和が認め られたことは，どのように説明できるであろうか。一 つの可能性は, 課題遂行全体の処理負荷が一定以上に 達していさえすれば，意味飽和を検出できるというも のである.つまり文字列の符号化のような語彙アクセ 又前の処理過程での負荷が高くなる場合でも，比較や 決定といった語彙アクセス後の処理過程での負荷が高 くなる場合であっても，どちらも意味飽和を検出でき ることになるわけである。意味的プライミング効果の 生起には語彙アクセス前の処理過程と, 語彙アクセス 後の処理過程の双方がかかわっているという指摘もあ り (Neely，1991)，それを考慮するとこの可能性には 十分な説得力がある。

一方で，抑制はどの表象レベルで生じているのかと いった問題もある．語彙判断課題ではプライミング効 果の減衰が認められず，カテゴリー判断課題では確認 
されてきた従来の知見では, 抑制は語彙レベルではな く, カテゴリー構造を反映する概念レベルで生じてい る可能性が想定された (Balota \& Black, 1997). カテ ゴリー判断課題ではターゲットがあるカテゴリーに含 まれるか否かを判断するために, ターゲットの意味的 特徵が検索され, 比較される必要がある (Smith, Shoben, \& Rips, 1974). Balota \& Black (1997) によ れば，抑制はこの過程で生じていると説明されてい る. しかし本研究や下木戸 (2003) で, 語彙判断課題 であってもプライミング効果の減衰が認められたこと によって, 抑制は語彙レベルで生じている可能性が示 唆された。またこれらの他にも語彙レベルで抑制が生 じていることを支持する知見がある（Black，2001； Sekiguchi, 1999).

抑制が語彙表象のレベルで生じているとするなら ば, それはあくまでも意味情報だけに限られるのであ ろうか. それとも音韻情報や形態情報に関しても同様 に抑制の影響が現れるのだろうか. Balota \& Black （1997）は同様の関心から，プライムとターゲットが 同じ韻を踏んでいるかを判定させる押韻判断 (rhyme decision）課題を用いて, 長時間プライムを反復させ た場合に音韻的プライミング効果が減じられるのかを 検討した。実験の結果は, 音韻的関連性 $\times$ 反復の交互 作用は有意ではなく, 音韻飽和ともいうべき現象は認 められなかった。この結果は飽和による抑制は意味情 報だけに現れる可能性を示唆するものではあるが, 語 の認知過程における音韻情報の影響力を考虑すると (Van Orden, 1987), Balota \& Black (1997) が音韻飽 和を検出できなかったのは単に音韻的プライミング効 果の効果量が飽和の影響を検出できるほどには大きく なかっただけなのかもしれない.実際に飽和の影響が 音韻情報や形態情報にも現れるのかを結論するために は, さらなる研究の蓄積を待つ必要がある.

\section{語彙判断課題の意義}

本研究において, 視覚的に劣化された単一文字列の 語彙判断課題で意味飽和が検出されたことに加え, 二 重語彙判断課題で意味飽和を見出した下木戸 (2003) の結果と併せると, 語彙判断課題であっても課題を複 雑にして処理負荷を高めたり, 意味的な関与を高めた りすれば意味飽和が検出できることが改めて示された といえる。意味飽和がどのようにして生起するのかに ついては, 音韻処理が重要な関わりをもっているとい う指摘もあるため (Esposito \& Pelton, 1971)，この処 理に関する研究知見の多い語彙判断課題を意味飽和の 研究に適用できる利点は少なくないと思われる，音韻 処理の観点からいえば，長時間同じ語を聞き続けてい ると，次第に音韻的に類似した別の語として聞こえる ようになる言語変容（verbal transformation）という 現象が知られている（Warren, 1968)。この現象と意
味飽和との関係を探る上でも語彙判断課題は有用であ るといえよう。

意味表象には, 語彙的なもの, 概念的なもの, 文法 的なもの, 情緒的なもの, 語用論・実用論的なものと いうように，様々な様相があると考えられる。これら のうち, 語彙判断課題は語彙的なものに焦点を当てる のに対し, カテゴリー判断課題は概念的なものに焦点 を当てていると捉えることができる。同じ語に長時間 接していることで感じられる意味の消失は, これらの ぞこに，どのような形で現れるのかに関しては，今後 も様々な課題を用いて検討していく必要があるだろ う.

\section{引用文献}

秋田 清 1980 50 のカテゴリーに属する語の出現 頻度表 人文学 (同志社大学人文学会), 135, 4287.

(Akita, K. 1980 The table of appearancefrequencies for verbal items in 50 categories. Jimbungaku, Studies in Humanities. (The Literary Association Doshisha University), 135, 42-87.)

Bajo, M. T., Burton, A., Burton, E., \& Canas, J. J. 1994 Word recognition across orthographies: Another look at the interaction between context and degradation. European Journal of Cognitive Psychology, 6, 171-193.

Balota, D. A., \& Black, S. 1997 Semantic satiation in healthy young and older adults. Memory \& Cognition, 25, 190-202.

Balota, D. A., \& Chumbley, J. I. 1984 Are lexical decisions a good measure of lexical access?: The role of word frequency in the neglected decision stage. Journal of Experimental Psychology: Human Perception and Performance, 10, 340-357.

Becker, C. A., \& Killion, T. H. 1997 Interaction of visual and cognitive effects in word recognition. Journal of Experimental Psychology: Human Perception and Performance, 3, 389-401.

Besner, D., \& Smith, M. C. 1992 Models of visual word recognition: When obscuring the stimulus yields a clearer view. Journal of Experimental Psychology: Learning, Memory, and Cognition, 18, 468-482.

Black, S. R. 2001 Semantic satiation and lexical ambiguity resolution. American Journal of Psychology, 114, 493-510.

Cohene, L. S., Smith, M. C., \& Klein, D. 1978 Semantic satiation revisited with a lexical decision task. Memory \& Cognition, 6, 131-140.

Esposito, N. J., \& Pelton, L. H. 1971 Review of the measurement of semantic satiation. Psychological Bulletin, 75, 330-346.

Kounios, J., Kotz, S. A., \& Holcomb, P. J. 2000 On 
the locus of the semantic satiation effect: Evidence from event-related brain potentials. Memory \& Cognition, 28, 1366-1377.

Lambert, W. E., \& Jakobovits, L. A. 1960 Verbal satiation and changes in the intensity of meaning. Journal of Experimental Psychology, 60, 376-383.

Lukatela, G., Carello, C., Peter, M., Lukatela, K., \& Turvey, M. T. 1996 Visual and associative factors in processing Serbo-Croatian words. European Journal of Cognitive Psychology, 8, 321-339.

Lukatela, G., \& Turvey, M. T. 1987 Loci of phonological effects in the lexical access of words written in a shallow orthography. Psychological Research, 49, 139-146.

Meyer, D. E., Schvaneveldt, R. W., \& Ruddy, M. G. 1975 Loci of contextual effects on visual word recognition. In P. M. A. Rabbit \& S. Dornic (Eds.), Attention and performance $V$. San Diego: Academic Press. Pp. 98-118.

Neely, J. H. 1977 The effects of visual and verbal satiation on a lexical decision task. American Journal of Psychology, 90, 447-459.

Neely, J. H. 1991 Semantic priming effects in visual word recognition: A selective review of current findings and theories. In D. Besner \& G. W. Humphreys (Eds.), Basic processes in reading : Visual word recognition. Hillsdale: Lawrence Erlbaum Associates. Pp. 264-336.

Neely, J. H., Keefe, D. E., \& Ross, K. L. 1989 Semantic priming in the lexical decision task: Roles of prospective prime-generated expectancies and retrospective semantic matching. Journal of Experimental Psychology: Learning, Memory, and Cognition, 15, 1003-1019.

小川嗣夫 197252 カテゴリに属する語の出現頻度 表 人文論究 (関西学院大学人文学会)，22, 1-68. (Ogawa, T 1972 Normative data for verbal items in 52 categories. Jimbun Ronkyu, Humanities Review (Journal of the Literary Association of Kwansei Gakuin University), 22, 1-68.)

Pilotti, M., Antrobus, J. S., \& Duff, M. 1997 The effect presemantic acoustic adaptation on semantic "satiation". Memory \& Cognition, 25, 305-312.

Sekiguchi, T. 1999 Locus of semantic satiation examined with a serial matching task. Perceptual and Motor Skills, 89, 753-759.

Severance, E., \& Washburn, M. F. 1907 The loss of associative power in the words after long fixation. American Journal of Psychology, 18, 182-186.

下木戸隆司 2003 二重語彙判断課題における意味飽 和の影響 心理学研究, 74, 45-50.

(Shimokido, T. 2003 The effect of semantic satiation on a double lexical decision task. Japanease Journal of Psychology, 74, 45-50.)

Smith, D. E. P., \& Raygor, A. L. 1955 Verbal satiation and personality. Journal of Abnormal and Social Psychology, 52, 323-326.

Smith, E. E., Shoben, E. J., \& Rips, L. J. 1974 Structure and process in semantic memory: A feature model for semantic decisions. Psychological Review, 81, 214-241.

Smith, L. C. 1984 Semantic satiation affects category membership decision time but not lexical priming. Memory \& Cognition, 12, 483-488.

Smith, L. C., \& Klein, R. 1990 Evidence for semantic satiation: Repeating a category slows subsequent semantic processing. Journal of Experimental Psychology: Learning, Memory, and Cognition, 16, 852-861.

Stanovich, K. E., \& West, R. F. 1979 Mechanisms of sentence context effects in reading: Automatic activation and conscious attention. Memory \& Cognition, 7, 77-85.

Van Orden, G. C. 1987 A ROWS is a ROSE: Spelling, sound and reading. Memory \& Cognition, 15, 181-198.

Warren, R. M. 1968 Verbal transformation effect and auditory perceptual mechanisms. Psychological Bulletin, 70, 261-270.

-2002. 10.16 受稿, 2003. 11.8 受理- 